Jurnal Sewaka Bhakti

Lembaga Penelitian dan Pengabdian Kepada Masyarakat

Universitas Hindu Indonesia Denpasar

Volume 2, Nomor 1 April 2019

ISSN: 2654-2935 (Online)

https://ejournal.unhi.ac.id/index.php/sewakabhakti

pp. 63-72

\title{
KOMPUTERISASI DALAM PROSES PENYUSUNAN LAPORAN KEUANGAN PADA USAHA SIMPAN PINJAM TAMBA ARTHA NADI TAMBAWU KAJA
}

\author{
Oleh \\ Ida Ayu Sasmita Dewi, Ni Wayan Alit Erlina Wati, Ni Wayan Yuniasih \\ Program Studi Akuntansi, Fakultas Ekonomi Bisnis dan Pariwisata \\ Universitas Hindu Indonesia \\ 081236726188/dayusasmitaunhi@gmail.com
}

\begin{abstract}
Abstrak
Laporan keuangan adalah bentuk pertanggungjawaban keuangan oleh manajemen kepada pemberi modal dalam sebuah usaha. Laporan keuangan yang baik adalah laporan keuangan yang menyajikan informasi yang relevan dan reliabel. Untuk menghasilkan laporan keuangan yang berkualitas diperlukan pemahaman yang cukup tentang prinsip akuntansi dan adanya sistem komputerisasi yang diharapkan dapat mempermudah pekerjaan manajemen.

Usaha simpan pinjam Tamba Artha Nadi merupakan salah satu usaha simpan pinjam yang dimiliki oleh Banjar Tembawu Kaja. Dalam proses penyusunan laporan keuangannya masih menggunakan catatan manual walau menggunakan computer sehingga ada risiko kesalahan. Pengabdian ini dimaksudkan untuk membantu manajemen Usaha Simpan Pinjam Tamba Artha Nadi dalam penyusunan laporan keuangan menggunakan aplikasi Microsoft Excel. Pendampingan ini diharapkan dapat membantu perusahaan untuk menyusun laporan keuangan yang sesuai dengan standar akuntansi keuangan.

Kegiatan pengabdian telah dilakukan dalam beberapa tahapan diantaranya observasi awal, penelaahan laporan yang ada, dan pendampingan perbaikan penyajian laporan keuangan dengan bantuan aplikasi Microsoft Excel. Aplikasi tersebut dirasa dapat memudahkan manajemen dalam penyusunan laporan mengingat kegiatan usaha yang masih relatif kecil. Manajemen juga dibantu untuk melakukan analisa rasio keuangan sehingga dapat dilihat perkembangan usaha dari tahun ke tahun.

Kata kunci: laporan keuangan, komputerisasi, rasio keuangan

\section{Pendahuluan}

Pada era globalisasi dan informasi seperti saat ini, lingkungan bisnis mengalami perubahan dan persaingan yang sangat ketat. Perusahaan dituntut untuk menjaga efektifitas dan efisiensinya sehingga kegiatan operasional perusahaan dapat berjalan lancar. Efektivitas dan efisiensi operasional sangat bergantung pada ketersediaan informasi. Bodnar dan Hopwood (2006:3) menyatakan bahwa
\end{abstract}


informasi adalah data yang berguna yang diolah sehingga dapat dijadikan dasar untuk mengambil keputusan yang tepat. Informasi yang baik adalah informasi yang berkualitas, akurat, relevan dan tepat waktu sehingga keputusan yang tepat dapat diambil sesuai dengan kondisi dan permasalahan yang ada.

Laporan keuangan merupakan salah satu informasi akuntansi. Informasi akuntansi yang dihasilkan dari serangkaian proses akuntansi yang meliputi pencatatan transaksi dalam dokumen, pencatatan dalam jurnal, posting dalam buku pembantu dan buku besar, kemudian akan dibuatkan neraca saldo, lalu dibuatkan jurnal penyesuaian, sesudah saldo disesuaikan makan akan menghasilkan neraca saldo setelah penyesuaian dan dari saldo tersebut barulah disusun laporan laba rugi, neraca dan laporan perubahan ekuitas.

Teknologi informasi (TI) dan komputer pada saat ini perkembangannya sangat pesat dan salah satu hasil dari perkembangan TI dan komputer ini adalah Sistem Informasi Akuntansi. Kejadian finansial yang terjadi dikomunikasikan melalui sistem infomasi akuntansi pada pihak yang berkepentingan berupa laporan-laporan kegiatan. Ketersediaan TI diharapkan dapat mempermudah perusahaan dalam mengolah transaksi keuangannya sehingga menghasilkan informasi keuangan yang valid dan reliabel.

Usaha simpan pinjam Tamba Artha Nadi merupakan usaha yang dimiliki oleh Banjar Tambawu Kaja Kelurahan Penatih Denpasar, beroperasi sejak tahun 1999 dengan modal awal berupa pinjaman Rp 3.000.000. Pinjaman tersebut merupakan dana bergulir dari kelurahan yang diberikan kepada setiap banjar oleh Lembaga Pemberdayaan masyarakat (LP) Kelurahan Penatih. Di akhir tahun 2018 usaha simpan pinjam Tamba Artha Nadi sudah mengelola asset sampai Rp 845.780.250,--

Berdasarkan wawancara dengan ketua Bapak I Ketut Sumasuara dengan keberadaan usaha simpan pinjam ini, adapun kelemahan yang dimiliki adalah bahwa usaha ini belum memiliki badan hukum dan ijin operasional sehingga kesulitan dalam memaksimalkan usaha. Usaha ini belum memiliki pencatatan yang 
memadai dari segi akuntansi untuk bisa menghasilkan laporan keuangan berkualitas dengan tepat waktu disetiap akhir bulannya, walo sudah menggunakan komputer dalam pencatatan tapi belum mampu menggunakan program excel dengan baik dilihat dari proses akuntansinya. Oleh karena itu penulis mengajukan proposal untuk melakukan pengabdian kepada masyarakat pada usaha simpan pinjam Tamba Artha Nadi.

Dalam pengabdian ini akan diberikan pelatihan secara rinci bagaimana cara proses penyusunan laporan dengan menggunakan format-format formulir yang memenuhi standar dalam proses penyusunan laporan keuangan menggunakan program excel sehingga dapat menghasilkan laporan keuangan yang berkualitas dan lebih cepat yang disertai dengan interprestasi dari angka-angka dalam laporan keuangan seperti angka-angka dalam neraca dan laporan laba rugi.

Hasil pengabdian ini diharapkan dapat digunakan sebagai bahan informasi bagi pemilik ataupun pengurus usaha simpan pinjam Tamba Artha Nadi, mengenai pentingnya mengetahui cara proses penyusunan laporan keuangan untuk pengambilan keputusan. Diharapkan dengan mengetahui proses penyusunan laporan keuangan yang benar dan lebih cepat maka pengurus dapat mengembangkan usahanya sehingga laporan yang sebelumnya disusun secara manual selanjutnya akan mulai terkomputerisasi dan dilengkapi dengan interprestasi dari angka-angka dalam laporan keuangan tersebut.

\section{Metode Pemecahan Masalah}

Adapun masalah yang dihadapi oleh Usaha Simpan Pinjam Tamba Artha Nadi akan diselesaikan dengan memberikan form penyusunan laporan keuangan dalam bentuk excel dan melakukan pelatihan penggunaan form tersebut. Dalam kegiatan akuntansi akan melalui berbagai proses didalamnya mulai dari transaksi keuangan hingga pembukuan/penyusunan laporan keuangan. Kegiatan yang terus menerus diulang itulah yang dinamakan dengan proses akuntansi. Proses akuntansi dibagi menjadi 3 tahap, yaitu: 
1. Tahap pencatatan dan penggolongan (pencatatan bukti transaksi keuangan). Mencatat setiap transaksi keuangan yang terjadi. Setelah data dicatat berdasarkan bukti transaksi berupa nota/kwitansi atau tanda transaksi lain selanjutnya menggolongkan pengeluaran tersebut. Tujuan penggolongan adalah untuk memudahkan dalam menganalisis data keuangan tersebut.

Tahapan pencatatan serta penggolongan transaksi keuangan antara lain:

a. Pembuatan/penyusunan bukti-bukti transaksi

b. Pencatatan setiap transaksi pada jurnal tertentu (jurnal umum atau khusus)

c. Catat hasil pencatatan di jurnal tersebut ke laporan buku besar.

2. Tahap peringkasan laporan keuangan. Tujuan peringkasan laporan keuangan untuk memudahkan dalam menganalisis data. Semakin ringkas dan jelas maka semakin bagus.

Tahapan peringkasan antara lain:

a. Merancang neraca saldo, datanya berasal dari saldo-saldo di buku besar

b. Menyusun jurnal penyesuaian, tujuannya untuk menyesuaikan fakta/keadaan yang sesungguhnya diakhir periode, serta menyusun neraca lajur yang digunakan untuk mempermudah dalam penyusunan laporan keuangan.

c. Pembuatan jurnal penutup untuk mengetahui tingkat laba dan rugi perusahaan.

d. Membuat neraca saldo setelah penutupan, diperlukan untuk mengecek pencatatan kembali pada periode selanjutnya.

e. Menggunakan informasi dari data tersebut untuk pengambilan keputusan.

f. Menyusun jurnal pembalik berfungsi untuk mengantisipasi kesalahan pencatatan pada periose selanjutnya

3. Tahap Laporan Keuangan atau Financial Statement. Tahapannya adalah sebagai berikut : 
a. Laporan Neraca (Balance Sheets) adalah laporan keuangan untuk menunjukkan posisi assets (aktiva), Liabilities (hutang), serta equity (modal)

b. Laporan Laba Rugi (Income Statements) adalah laporan keuangan yang terdiri dari seluruh beban pengeluaran serta pendapatan sehingga diperoleh nilai laba dan rugi.

c. Laporan Perubahan Modal (Equity Statements) adalah inti dari laporan keuangan yang berisi informasi tentang perubahan modal perusahaan.

d. Laporan Arus Kas (Cash Flow Statements) adalah bagian dari laporan keuangan dalam periode tertentu dalam periode tertentu yang berisi aliran dana kas baik masuk ataupun keluar. Biasanya digolongkan berdasarkan arus kas dari aktivitas investasi, aktivitas operasi, serta aktivitas pendanaan.

e. Catatan atas laporan keuangan adalah laporan tambahan yang berisi catatan informasi yang lebih detail tentang akun tertentu sehingga memberikan nilai yang lebih komprehensif dari suatu laopran finansial perusahaan.

4. Interprestasi yang menghubungkan angka-angka dalam laporan keuangan yang dilihat dari modal (capital), aktiva (assets quality), laba (earnings) dan likuiditas (liquidity).

5. Adapun dengan rumusan sebagai berikut :

a. Modal (capital) menggunakan Capital Adequacy Ratio (CAR), yaitu merupakan rasio yang membandingkan antara modal dengan aktiva tertimbang menurut resiko (ATMR).

b. Kualitas aktiva (Assets Quality) menggunakan Return On Risked Asset (RORA) yaitu perbandingan antara laba kotor dengan pinjaman yang diberikan.

c. Laba (earnings) menggunakan rasio ROA yaitu perbandingan laba setahun sebelum pajak dengan total asset.

d. Likuiditas (liquidity) menggunakan Loan to Deposit Ratio (LDR) yaitu rasio kredit yang diberikan dengan dana pihak ke tiga. 
Melihat permasalahan yang dihadapi oleh manajemen usaha simpan pinjam Tamba Artha Nadi, ada beberapa cara yang akan dilakukan dalam pengabdian masyarakat ini antara lain wawancara secara mendetail dilakukan dengan pengurus yaitu ketua dan sekretaris yang selama ini lebih banyak mengetahui tentang kondisi usaha simpan pinjam berkaitan dengan data-data pembukuan yang sudah dimiliki untuk ditelaah dan dikaji mengenai kekurangan-kekurangannya dilihat dari pencatatan akuntansi. Observasi yaitu melakukan tinjauan langsung ke tempat usaha untuk melihat secara langsung berkaitan dengan aktivitas pencatatan yang dilakukan pada saat terjadi transaksi sesungguhnya dan pelatihan yaitu memberikan pelatihan dalam menggunakan program excel dengan menggunakan komputer dari penerimaan kas, pembuatan jurnal, buku pembantu utang seperti tabungan yang dimiliki oleh masing-masing nasabah, buku pembantu piutang yang dimiliki oleh masing-masing debitur, buku besar, neraca saldo, laporan laba rugi, neraca dan laporan perubahan modal. Pelatihan dalam melakukan interprestasi angka-angka dalam laporan keuangan untung mendapatkan rasio keuangan seperti rasio capital, asset, earnings dan likuiditas.

\section{Hasil Dan Pembahasan}

Pelaksanaan kegiatan pengabdian ini dibagi secara bertahap yaitu pada tahap awal dilakukan wawancara dan observasi. Wawancara dengan Ketua Usaha Simpan Pinjam (USP) mengenai kepastian hukum usaha, bahwa USP Tamba Artha Nadi sampai saat ini belum memiliki badan hukum, walau dalam membuat laporan sudah memakai logo koperasi. Usaha ini ada rencana mengajukan izin menjadi kopersi tetapi terkendala oleh keanggotaan mengingat asset yang dikelola saat ini bukan berasal dari anggota masyarakat, melainkan bersumber dari dana bergulir Lembaga Pemberdayaan Masyarakat Kelurahan pada tahun 1999 yang dikelola dan sudah mampu dikembalikan secara penuh pada LPM. Kalau koperasi modal usaha bersumber dari anggota berupa simpanan pokok dan simpanan wajib. Hasil dari dana bergulir dari LPM kelurahan tersebut di tahun 2012 asset yang dimiliki usaha 
simpan pinjam sudah mencapai tiga puluh jutaan. Asset kotor yang dikelola pada Bulan Desember tahun2018 sudah mencapai Rp 845.780.250,- .

Pengelolaan USP dilakukan oleh empat orang yaitu terdiri dari : 1). Ketua: I Ketut SumaSuara,2). Bendahara : I Nyoman Suarsa,3). Operasional I: I Made Sangra, 4). Operasional II: I Wayan Dita

Dalam aktivitas operasional terjadi perangkapan tugas dan saling membantu satu sama lain mengingat USP Tamba Artha Nadi i assetnya masih belum terlalu besar, serta jam kerja hanya sekitar $2 \frac{1}{2} 2$ jam diwaktu malam hari dari jam setengah 8 sampai jam sepuluh malam. Ketua merangkap membuat pelaporan keuangan, kebetulan ketua dalam keseharian bekerja di Lembaga Perkreditan Desa Tambawu. Pertanggungjawaban laporan hanya dilakukan pada anggota banjar setiap tahunnya, pada saat parumam rutin bulanan dari banjar Tambawu kaja.

Adapun laporan yang dibuat USP ini terdiri dari : 1) buku kas harian, buku mutasi dari semua akun yang dibuat yang hampir sama dengan buku besar langsung terhubung dengan semua transaksi harian yang dilakukan, 2) neraca lajur yang berisi nama akun,neraca percobaan yang merupakan mutasi dari semua transaksi yang ada, neraca sisa, rugi-laba dan neraca akhir. 3) buku saldo tabungan akhir periode yang berisi: nama penabung, saldo awal, mutasi, bunga dan saldo akhir, 4) buku sisa pinjaman yang berisi : nama peminjam, saldo awal mutasi dan sisa pinjaman.

Penyusunan pelaporan yang dibuat USP sudah menggunakan program excel namun belum menggunakan rumus-rumus excel yang memadai untuk bisa menghasilkan laporan yang lebih lengkap dan bisa berhubungan antara satu laporan dengan laporan lainnya. Karena USP belum membuat laporan keuangan seperti laporan laba rugi, Neraca dan laporan perubahan modal serta belum melakukan melakukan analisis laporan keuangan yang dihasilkan.

Sisa Hasil Usaha (SHU) atau laba yang dihasilkan dibagikan sebagai berikut : Cadangan Modal 40\%, Cadangan Pembangunan Banjar 20\%, Cadangan Pesangon 10\%, Cadangan Pinjaman Ragu-Ragu 5\%, Dana Sosial 10\%, Jasa 
Produksi 10\%, dan Dana Pengurus 5\%. Seharusnya cadangan pinjaman ragu-ragu sebagai biaya yang dikeluarkan setiap akhir periode akuntansi, bukan dari persentase laba.

Tahap selanjutnya, setelah mendapatkan data mengenai laporan yang dibuat berupa soft copynya kami dalam tim melakukan perubahan -perubahan sesuai cara-cara dalam membuat laporan keuangan yang mesti dihasilkan dari USP dari membuat jurnal, buku pembantu, buku besar, Neraca Saldo, Neraca lajur dan laporan Keuangan yang terdiri dari Neraca, laporan laba Rugi, Laporan perubahan modal. Selanjutnya kami melakukan pelatihan untuk menerapkan aplikasi Microsoft excel tersebut, setelah dilakukan perbaikan-perbaikan karena kesalahan dalam penempatan saldo dari suatu akun, membuat buku pembantu utang dan piutang, membuat laporan keuangan berupa neraca, laporan laba rugi dan laporan perubahan modal sekaligus bagaimana cara menerapkan rumus-rumus dalam analisis laporan keuangan yang dibuat.

Usaha simpan Pinjam Laporan tamba Artha Nadi karena kendala sumber modal yang bukan dari anggota masyarakat, dari segi permodalan belum bisa berbadan hukum koperasi sampai saat ini, berdasarkan wawancara dengan ketua, untuk sementara akan iusahakan dalam bentuk USP yang menjadi milik penduduk asli saja karena pertimbangan mereka tidak akan pindah tempat tinggal, sehingga dapat membantu dalam kegiatan bermasyarakat di tingkat banjar.

Dalam pengabdian ini kami melengkapi laporan yang dibuat dengan membuat kan berupa : Buku Pembantu Utang,, Buku Pembantu Piutang, Neraca Saldo, Neraca Lajur yang benar karena ada penempatan akun yang masih salah dalam neraca percobaannya yaitu penempatan saldo akun akumulasi penyusutan inventari di debet tetapi dengan nilai mines, Laporan keuangan berupa : laporan laba rugi, neraca, dan laporan yang berbentuk soft copy khusus tersimpan dalam satu flahdisk, yang sudah bisa saling berhubungan sesuai dengan proses penyusunan laporan keuangan. 
Adapun prosesmya diawali dengan: bukti transaksi, jurnal dan buku pembantu, buku besar, neraca saldo, neraca lajur, laporan keuangan yang terdiri dari laporan laba rugi, neraca dan laporan perubahan modal.

Semua yang dibuat dalam pengabdian ini diserahkan dalam bentuk soft copy tersimpan dalam flasdisk untuk hard copy terlampir.,terdiri dari Neraca lajur yang merujuk pada apa yang telah dibuat oleh USP, buku pembantu utang dan piutang, Laporan Laba Rugi, Neraca Dan laporan Perubahan Modal.

Hasil analisis laporan keuangan 31 Desember 2018 adalah:

Kinerja dari segi permodalan, untuk mengetahui kemampuan USP menutupi penurunan aktiva akibat terjadinya kerugian-kerugian atas aktiva USP dengan menggunakan modal sendiri rasio Capital Adequicy Ratio (CAR) sebesar 0,240 atau $24 \%$. Dari segi asset melalui kualitas produktifnya digunakan Return On Risked Asset (RORA) yaitu membandingkan laba kotor dengan pinjaman yang nilai yang diperoleh sebesar 0,091 atau 9,1\%, untuk kemampuan USP dalam menghasilkan keuntungan dibandingkan dengan nilai total rata-rata assetnya menggunakan Return On Asset (ROA) dengan nilai 0,0778 atau 7,8 \% dan rasio likuiditas dihitung dengan menggunakan Loan to Deposit Ratio (LDR) yaitu dengan membandingkan pinjaman yang diberikan dengan dana pihak ke tiga, adapun nilainya sebesar 1,2439 atau $124,4 \%$

Dari hasil rasio perhitungan rasio yang terdiri dari CAR menunjukkan kemampuan USP dalam menanggulangi apabila terjadi kerugian adalah sebesar $24 \%$, dari segi kualitas produktifnya menunjukkan nilai $91 \%$ berarti dari pinjaman yang diberikan mampu memberikan laba sebesar hanya 9,1\% di tahun 2018, nilai ROA sebesar 7,8 \% berarti kemampuan menghasilkan laba dilihat dari asset yang digunakan hanya $7,8 \%$ pada tahun 2018 , dan rasio likuiditas dengan nilai $124,4 \%$ berarti $24,4 \%$ pinjaman dibiayai oleh modal sendiri.

\section{Kesimpulan Dan Saran}

Berdasarkan uraian permasalahan dan hasil pemecahan masalah dapat disimpulkan beberapa hal antara lain: 1).Kegiatan pengabdian masyarakat berupa 
komputerisasi dalam proses penyusunan laporan keuangan pada usaha simpan pinjam Tamba Artha Nadi Tambawu Kaja telah terlaksana dengan baik. 2).Kegiatan pengabdian telah menghasilkan format laporan keuangan yang sesuai dengan standar akuntansi keuangan dalam format excel yang memudahkan manajemen dan pengguna informasi untuk memahami isi dari laporan keuangan tersebut. Kegiatan pengabdian seperti ini dapat dilakukan secara rutin baik di lokasi yang sama maupun di lokasi yang berbeda dengan sasaran masyarakat yang benarbenar membutuhkan pendampingan dalam penyusunan laporan keuangan sehingga usaha yang dibuat semakin berkembang dan menghasilkan laporan keuangan yang berkualitas.

\section{Ucapan Terima Kasih}

Pengabdian masyarakat ini telah terlaksana dengan baik karena dukungan dari berbagai pihak. Oleh karena itu, kami selaku penulis ingin mengucapkan terima kasih kepada beberapa pihak antara lain: Terima kasih kepada Lembaga Penelitian dan Pengabdian Kepada Masyarakat Universitas Hindu Indonesia atas hibah dana yang diberikan untuk melaksanakan pengabdian ini, kepada segenap jajaran pengurus Usaha Simpan Pinjam Tamba Artha Nadi yang telah bersedia menjadi mitra dalam pelaksanaan pengabdian masyarakat ini. Serta terima kasih kepada pihak lain yang tidak dapat disebutkan satu per satu atas bantuannya dalam menyelesaikan pengabdian ini.

\section{Daftar Pustaka}

Erhans A. 2001. Microsoft Excel 2002. PT Ercontara Rajawali: Jakarta Pusat Johar Arifin. 2017. Mengupas Kedasyatan 340 Fungsi Terapan Microsoft Excel 2016. Kompas Gramedia

Jusup, Al. Haryono. 2017. Dasar-Dasar Akuntansi Jilid 1. STIE YKPN: Yogyakarta.

Jusup, Al. Haryono. 2017. Dasar-Dasar Akuntansi Jilid 2. STIE YKPN: Yogyakarta. 